\title{
https://www.dothideomycetes.org: An online taxonomic resource for the classification, identification, and nomenclature of Dothideomycetes
}

\author{
Pem $\mathrm{D}^{1}$, Hongsanan $\mathrm{S}^{2}$, Doilom $\mathrm{M}^{3}$, Tibpromma $\mathrm{S}^{3}$, Wanasinghe $\mathrm{DN}^{3}$, Dong $\mathrm{W}^{1}$, \\ Liu NG ${ }^{1}$, Phookamsak $R^{3}$, Phillips $\mathrm{AJL}^{4}$, Jeewon $\mathbf{R}^{5}$ and Hyde $\mathrm{KD}^{1,3 *}$ \\ ${ }^{1}$ Center of Excellence in Fungal Research, Mae Fah Luang University, Chiang Rai, Thailand \\ ${ }^{2}$ College of Life Science and Oceanography, Shenzhen University, 1068, Nanhai Avenue, Nanshan, Shenzhen 518055, \\ People's Republic of China \\ ${ }^{3}$ Key Laboratory for Plant Diversity and Biogeography of East Asia, Kunming Institute of Botany, Chinese Academy of \\ Sciences, Kunming 650201, People's Republic of China \\ ${ }^{4}$ Faculty of Sciences, Biosystems and Integrative Sciences Institute (BioISI), Universidade de Lisboa, Lisbon, Portugal \\ ${ }^{5}$ Department of Health Sciences, Faculty of Science, University of Mauritius, Reduit, Mauritius
}

Pem D, Hongsanan S, Doilom M, Tibpromma S, Wanasinghe DN, Dong W, Ningguo L, Phookamsak R, Phillips AJL, Jeewon R, Hyde KD 2019 - https://www.dothideomycetes.org: An online taxonomic resource for the classification, identification, and nomenclature of Dothideomycetes. Asian Journal of Mycology 2(1), 287-297, Doi 10.5943/ajom/2/1/19

\section{Abstract}

The number of species, genera, families and orders currently known to science in the class Dothideomycetes are rapidly changing with updated phylogenetic data but there are challenges ahead in dealing with the vast amount of taxonomic data scattered in the literature. In order to provide a suitable platform to bring all this data together, a website https://www.dothideomycetes.org has been set up and is explained in this paper. This website provides comprehensive and updated information including detailed descriptions of voucher specimens, color photographs, illustrations, notes, phylogenetic trees, estimated numbers of species in each genus, number of species with molecular data and other useful information related to fungi that belong to the Dothideomycetes. The webpage has a head curator, managing curator and several curators with appropriate taxonomic expertise. This work is funded by the Mushroom Research Foundation, an NGO comprising seven directors trained in mycology.

Keywords - Ascomycota - Bitunicate fungi - Dothideomycetes genera - Dothideomycetes webpage - taxonomy

\section{Introduction}

The classification and nomenclature of Dothideomycetes have undergone considerable changes during the past decade and to-date this cosmopolitan class contains 36 orders and 202 families (Hongsanan et al. 2020). Traditionally the most important morphological characteristics used to define major groups in Dothideomycetes were based on the morphology of the development of the ascomata, peridium, type of the asci, ascospores and the hamathecium. (Hyde et al. 2013, 2019, Phookamsak et al. 2019). Traditionally the class was classified based on three main characters viz. the developments of the bitunicate, fissitunicate asci, hamathecium 
(pseudoparaphyses) and pseudothecial ascomata (Barr 1983, 1984). Recently, the molecular phylogeny and the sexual-asexual morph connections become essential tools to classify the genera in Dothideomycetes coupled with morphological characteristics (Luo et al. 2017, Karunarathna et al. 2017). The class Dothideomycetes comprises two subclasses Dothideomycetidae (absence of pseudoparaphyses) and Pleosporomycetidae (presence of pseudoparaphyses) (Schoch et al. 2006, 2009, Liu et al. 2017).

An inclusive account of the genera of Dothideomycetes was provided by Hyde et al. (2013) to revise the taxonomic status of the class Dothideomycetes. Another recent milestone is the 'Naming and outline of Dothideomycetes-2014 including proposals for the protection or suppression of generic names' published by Wijayawardene et al. (2014). In their work, the authors accepted 1261 genera in 23 orders and 110 families and proposed single generic names following the change of the International Code of Nomenclature for algae, fungi, and plants (ICN) rule and emphasizing on 'one fungus-one name'. In line with the 'one fungus-one name', Rossman et al. (2015) provided recommendations of one name for use among pleomorphic genera in the class Dothideomycetes by the Working Group on Dothideomycetes recognized under the auspices of the International Commission on the Taxonomy of Fungi (ICTF). Wijayawardene et al. (2017) also summarized the state of knowledge and revised the classification of the Dothideomycetes in 'Notes for genera: Ascomycota'. These publications represented major advances in the taxonomy of Dothideomycetes and since then many attempts have been made to provide a natural classification of genera within Dothideomycetes (Wanasinghe et al. 2017a, b, Jayasiri et al. 2019). Other important highlights are those of Boonmee et al. (2011, 2014, 2017), Chomnunti et al. (2011, 2014), Ariyawansa et al. (2014a, 2015), Dai et al. (2014), Hongsanan et al. (2014), Li et al. (2014), Phookamsak et al. (2014, 2015a, b, 2016, 2017), Thambugala et al. (2014a, b), Tian et al. (2016), Thambugala et al. (2014a, b), Jayasiri et al. (2016), Tian et al. (2016), Boonmee et al. (2017) and Doilom et al. (2018) who studied Dothideomycetes genera that were poorly described.

Following the outline of Ascomycota 2009 which included 41 families and 116 genera in Dothideomycetes, genera incertae sedis, many subsequent authors attempted to refine the natural placements of the Dothideomycetes, genera incertae sedis based on the studies of the type specimens (Lumbsch \& Huhndorf 2010, Ariyawansa et al. 2013, 2014b, Hyde et al. 2013, Dai et al. 2014, Li et al. 2014, Thambugala et al. 2014a, b, Jayasiri et al. 2016, Boonmee et al. 2017, Doilom et al. 2018). Ariyawansa et al. (2014a) examined the generic types of Cucurbidothis, Heterosphaeriopsis, Hyalosphaera, Navicella and Pleiostomellina. Cucurbidothis has been referred to the Cucurbitariaceae while Navicella and Pleiostomellina were transferred to Melanommataceae and Parmulariaceae respectively. Heterosphaeriopsis and Hyalosphaera were retained in Dothideomycetes, genera incertae sedis. Dai et al. (2014) placed Muellerites in Dothidotthiaceae, Vizellopsis in Asterinaceae and retained Trematosphaeriopsis and Yoshinagella in Dothideomycetes, genera incertae sedis. Li et al. (2014) accommodated Lophiosphaerella in Mycosphaerellaceae and referred Bryopelta to Mycosphaerellaceae incertae sedis while Maireella accommodated in Venturiaceae. Thambugala et al. (2014a) studied the morphology of the type specimens of Dolabra, Placostromella, Pleosphaerellula, Polysporidiella and Pseudotrichia and referred Dolabra to Chaetothyriomycetidae, genera incertae sedis (Eurotiomycetes); Placostromella to Parmulariaceae, Pleosphaerellula to Pleosporales, genera incertae sedis, Polysporidiella to Dothideomycetes, genera incertae sedis and Pseudotrichia to Montagnulaceae respectively based on morphology. Thambugala et al. (2014b) referred Allosoma to Englerulaceae; Austropleospora and Karschia to Pleosporaceae and Lichenotheliaceae respectively; Dangeardiellais in Pleosporales, genera incertae sedis and Griggsia in Sordariomycetes, genera incertae sedis. Likewise, in another similar publication, Jayasiri et al. (2016) confirmed the placement of Cocconia, Endococcus and Lineostroma in the families Parmulariaceae, Lichenotheliaceae and Didymosphaeriaceae respectively and retained Dianesea in Dothideomycetes genera incertae sedis. Boonmee et al. (2017) studied many type materials of the Ascomycota, genera incertae sedis and introduced 13 new families in Dothideomycetes. Doilom et al. (2018) established Johansoniaceae as a new family and transferred Rivilata and Vonarxella from 
Saccardiaceae to Phaeothecoidiellaceae and Schizothyriaceae, respectively. There are constant taxonomic changes, including updates to the existing and introduction of new species, added to this class and the taxonomy is always in a transitional state (Zhang et al. 2012, Phillips et al. 2013, Liu et al. 2015, Hyde et al. 2016, Phookamsak et al. 2017). In the updated outline of Ascomycota 2017 (Wijayawardene et al. 2018), 1138 genera listed under the class Dothideomycetes and 238 genera listed under Dothideomycetes, genera incertae sedis (genera that have not been confirmed by their familial placement) have to be illustrated and described based on morphology and phylogeny.

\section{Database and the need for Dothideomycetes webpage}

The current concepts on Dothideomycetes classification and the taxonomic methods used are changing rapidly and hence, establishing an appropriate database is crucial for bringing scattered data together as well as for proper dissemination of information worldwide. With the advent of DNA sequence-based phylogenetic analyses, novel species, genera, families and orders are being discovered (Doilom et al. 2017, Tibpromma et al. 2017, Wanasinghe et al. 2018, Hyde et al. 2018, 2019, Phookamsak et al. 2015b, 2017, 2019, Zhang et al. 2019). Due to this rapid evolution and discovery, it is important to realize the need for curated databases that serve to provide an overview of the evolutionary and taxonomic framework of these fungi (Jayasiri et al 2015, Monkai et al. 2019).

Therefore, the primary objective of the website is to bring all this information together in a single comprehensive database and produce a compilation of previous as well as updated treatments within the class Dothideomycetes. The purpose of the Dothideomycetes fungi webpage is to 1) provide an up-to-date outline of the Dothideomycetes, 2) provide notes on orders, families and genera of Dothideomycetes, and 3) provide updated accounts of each genus keeping abreast of the current literature and new developments. The website will also provide a list of references dealing with Dothideomycetes. The webpages include a list of recent publications and a history of Dothideomycetes classification. Various websites deal with microfungi such as the fungal genera (http://www.fungalgenera.org, Monkai et al. 2019), the world register of marine species (http://www.marinespecies.org, Jones et al. 2019), and the faces of fungi (http://www.facesoffungi.org, Jayasiri et al. 2015), but, none of them deals specifically with Dothideomycetes.

\section{Dothideomycetes website}

This website provides basic and updated data on all taxonomic aspects of the Dothideomycetes. Recent notes concerning the placement and taxonomic status will be provided for each genus and will be updated periodically. Other information provided in each entry is directly related to the importance of the genera to humans or the ecosystem, industrial applications, quarantine regulations and biochemical potential, chemical diversity or applications. We will organize each genus, with descriptions, photographic plates, phylogenetic trees, lists of accepted species in each genus and include significant information through the links from other associated webpages namely, the fungal genera (https://www.fungalgenera.org, Monkai et al. 2019), Faces of Fungi (http://www.facesoffungi.org, Jayasiri et al. 2015), One Stop Shop: (https://www.onestopshopfungi.org, Jayawardena et al. 2019), Marine fungi: (http://www.marinefungi.org, Jones et al. 2019) and other forthcoming webpages (Monkai et al. 2019, Jayawardena et al. 2019).

Mycologists, taxonomists and researchers from various fields of expertise are invited from all over the world to contribute to this webpage, monitor information and suggest improvements. The Dothideomycetes webpage will provide a better understanding of existing knowledge of Dothideomycetes genera and contribute to developing knowledge in the field of taxonomy.

\section{Construction}

All fungi included in the Dothideomycetes website are listed according to the most recent classification (Wijayawardene et al. 2017, 2018). The database will include only fungi of the class 
Dothideomycetes. It comprises the following headings: Home, Outline, Archives, Curators, History, References, News and Contact. Contributions will include descriptions, photographic plates, notes, phylogenetic trees and related data. For each entry, Faces of Fungi, Index Fungorum, MycoBank, herbaria, and GenBank accession numbers for sequence data if available for the illustrated species will be provided. The website has curators with mycological expertise who contribute to the increased knowledge and carry out a follow-up of updated data on the classification of Dothideomycetes fungi (Table 1).

\section{Database interface and visualization}

The website https://www.dothideomycetes.org/archives.php consists of many features that allow users to access data in an easy and friendly way. The homepage provides a general overview of the Dothideomycetes, the primary goals of setting up the webpage, and the 'highlights of information'. The left side of the homepage comprises recent news and recent genera published related to the Dothideomycetes. The option to find the information of genera includes:

1. Use the search box on the right-hand side of the homepage to search for a genus name.

2. Clicking on the genus name will reveal data on the genus, type species, relevant herbarium or reference material, classification, phylogeny, economic significance, importance and significant role in the scientific community.

Other useful tools include (Figs. 1-5):

1. Home: The homepage provides an overview of the class Dothideomycetes, goals of the website and 'Highlights of Information'.

2. Outline: The 'Outline' provides recent taxonomic classification of the genera, families and order of the Dothideomycetes.

3. Archives: The 'Archives' provides more information about a specific order or family.

4. Curators: This section provides the list and contact details of the curators of the website.

5. History: This section provides a brief history in the classification of Dothideomycetes.

6. References: This section provides reference list of citations used in the entries, history and related information.

7. News: The 'News' section publishes any event or announcement in the field of Mycology.

8. Contact: The 'Contact' section provides contact details of the website and allow users to address any comments and suggestions.

Table 1 List of expert curators for Dothideomycetes webpage.

\begin{tabular}{|c|c|c|c|}
\hline Position & Name & Address & Contact details \\
\hline $\begin{array}{l}\text { Head } \\
\text { Curator }\end{array}$ & $\begin{array}{c}\text { Sinang } \\
\text { Hongsanan }\end{array}$ & $\begin{array}{l}\text { Shenzhen Key Laboratory of Microbial } \\
\text { Genetic Engineering, College of Life } \\
\text { Sciences and Oceanography, Shenzhen } \\
\text { University, Shenzhen 518060, People's } \\
\text { Republic of China }\end{array}$ & sinang333@gmail.com \\
\hline $\begin{array}{c}\text { Managing } \\
\text { Curator }\end{array}$ & Dhandevi Pem & $\begin{array}{l}\text { Center of Excellence in Fungal } \\
\text { Research, Mae Fah Luang University, } \\
\text { Chiang Rai 57100, Thailand }\end{array}$ & pem.dhandevi@gmail.com \\
\hline \multirow[t]{3}{*}{ Curators } & Alan J.L. Phillips & $\begin{array}{l}\text { Biosystems and Integrative Sciences } \\
\text { Institute (BioISI), Faculdade de } \\
\text { Ciências, Universidade de Lisboa, } \\
\text { Lisbon, Portugal }\end{array}$ & alan.jl.phillips@gmail.com \\
\hline & Damien Ertz & National Botanic Garden of Belgium & damien.ertz@jardinbotaniquemeise.be \\
\hline & $\begin{array}{l}\text { Dhanushka N. } \\
\text { Wanasinghe }\end{array}$ & $\begin{array}{l}\text { Key Laboratory for Plant Diversity and } \\
\text { Biogeography of East Asia, Kunming } \\
\text { Institute of Botany, Chinese Academy } \\
\text { of Science, Kunming 650201, Yunnan, } \\
\text { People’s Republic of China }\end{array}$ & dnadeeshan@gmail.com \\
\hline
\end{tabular}


Table 1 Continued.

\begin{tabular}{|c|c|c|c|}
\hline Position & Name & Address & Contact details \\
\hline & Jing Yang & $\begin{array}{l}\text { Center of Excellence in Fungal } \\
\text { Research, Mae Fah Luang University, } \\
\text { Chiang Rai 57100, Thailand }\end{array}$ & yangjing5633@gmail.com \\
\hline & Kevin D. Hyde & $\begin{array}{l}\text { Center of Excellence in Fungal } \\
\text { Research, Mae Fah Luang University, } \\
\text { Chiang Rai 57100, Thailand }\end{array}$ & kdhyde3@gmail.com \\
\hline & $\begin{array}{l}\text { Mingkwan } \\
\text { Doilom }\end{array}$ & $\begin{array}{l}\text { Key Laboratory for Plant Diversity } \\
\text { and Biogeography of East Asia, } \\
\text { Kunming Institute of Botany, Chinese } \\
\text { Academy of Science, Kunming } \\
\text { 650201, Yunnan, People’s Republic of } \\
\text { China }\end{array}$ & j_hammochi@hotmail.com \\
\hline & Ning-Guo Liu & $\begin{array}{l}\text { Center of Excellence in Fungal } \\
\text { Research, Mae Fah Luang University, } \\
\text { Chiang Rai 57100, Thailand }\end{array}$ & liuningguo11@gmail.com \\
\hline & $\begin{array}{c}\text { Rungtiwa } \\
\text { Phookamsak }\end{array}$ & $\begin{array}{l}\text { Key Laboratory for Plant Diversity } \\
\text { and Biogeography of East Asia, } \\
\text { Kunming Institute of Botany, Chinese } \\
\text { Academy of Science, Kunming } \\
\text { 650201, Yunnan, People’s Republic of } \\
\text { China }\end{array}$ & $\begin{array}{l}\text { jomjam.rp2@gmail.com; } \\
\text { rphookamsak@outlook.com }\end{array}$ \\
\hline & $\begin{array}{l}\text { Saowaluck } \\
\text { Tibpromma }\end{array}$ & $\begin{array}{l}\text { Key Laboratory for Plant Diversity } \\
\text { and Biogeography of East Asia, } \\
\text { Kunming Institute of Botany, Chinese } \\
\text { Academy of Science, Kunming } \\
\text { 650201, Yunnan, People’s Republic of } \\
\text { China }\end{array}$ & saowaluckfai@gmail.com \\
\hline & $\begin{array}{l}\text { Saranyaphat } \\
\text { Boonmee }\end{array}$ & $\begin{array}{l}\text { Center of Excellence in Fungal } \\
\text { Research, Mae Fah Luang University, } \\
\text { Chiang Rai 57100, Thailand }\end{array}$ & saranyaphat.khag2@gmail.com \\
\hline & Wei Dong & $\begin{array}{l}\text { Center of Excellence in Fungal } \\
\text { Research, Mae Fah Luang University, } \\
\text { Chiang Rai 57100, Thailand }\end{array}$ & dongwei0312@hotmail.com \\
\hline
\end{tabular}

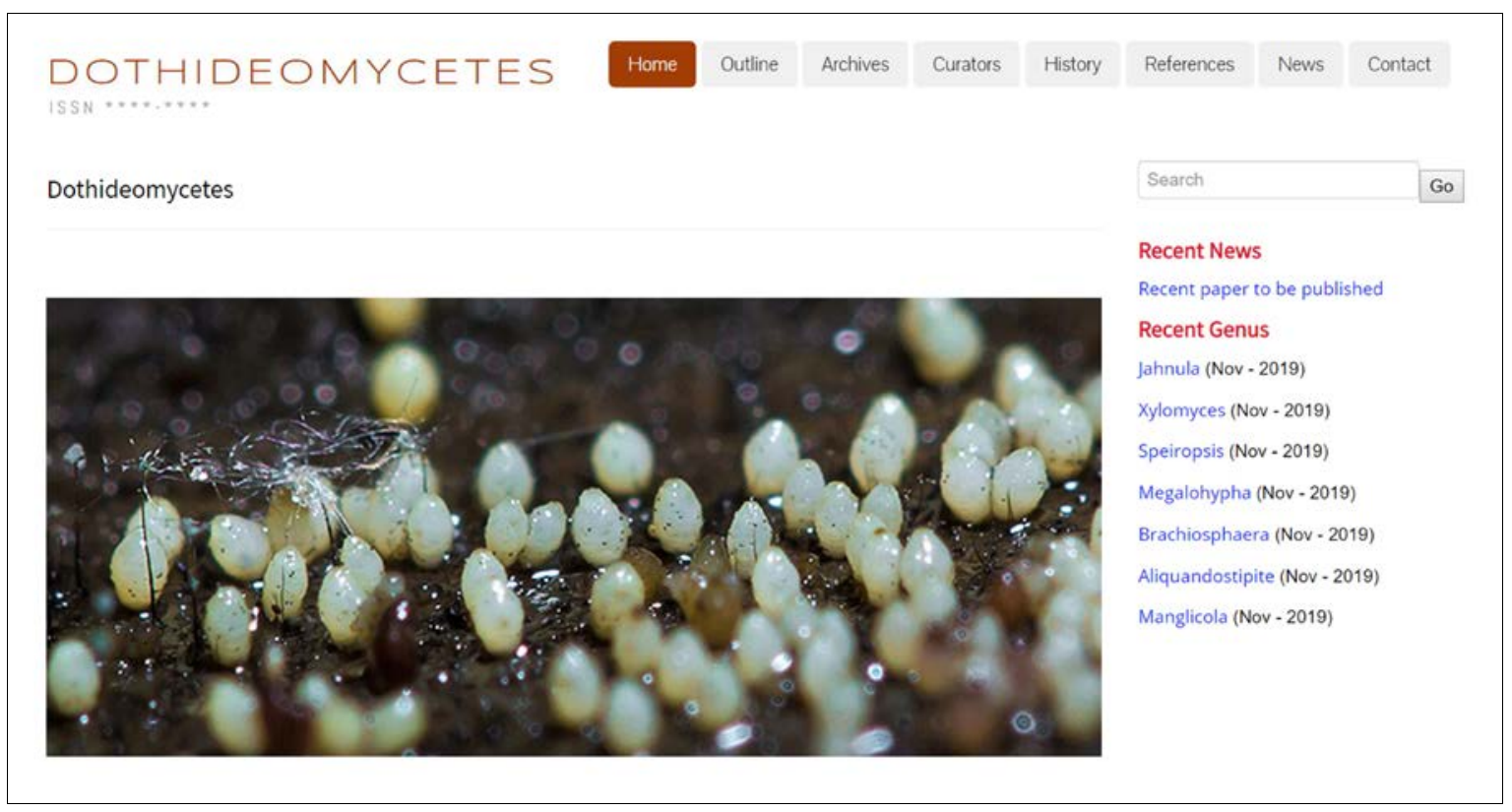

Fig. 1 - The homepage view of Dothideomycetes webpage 


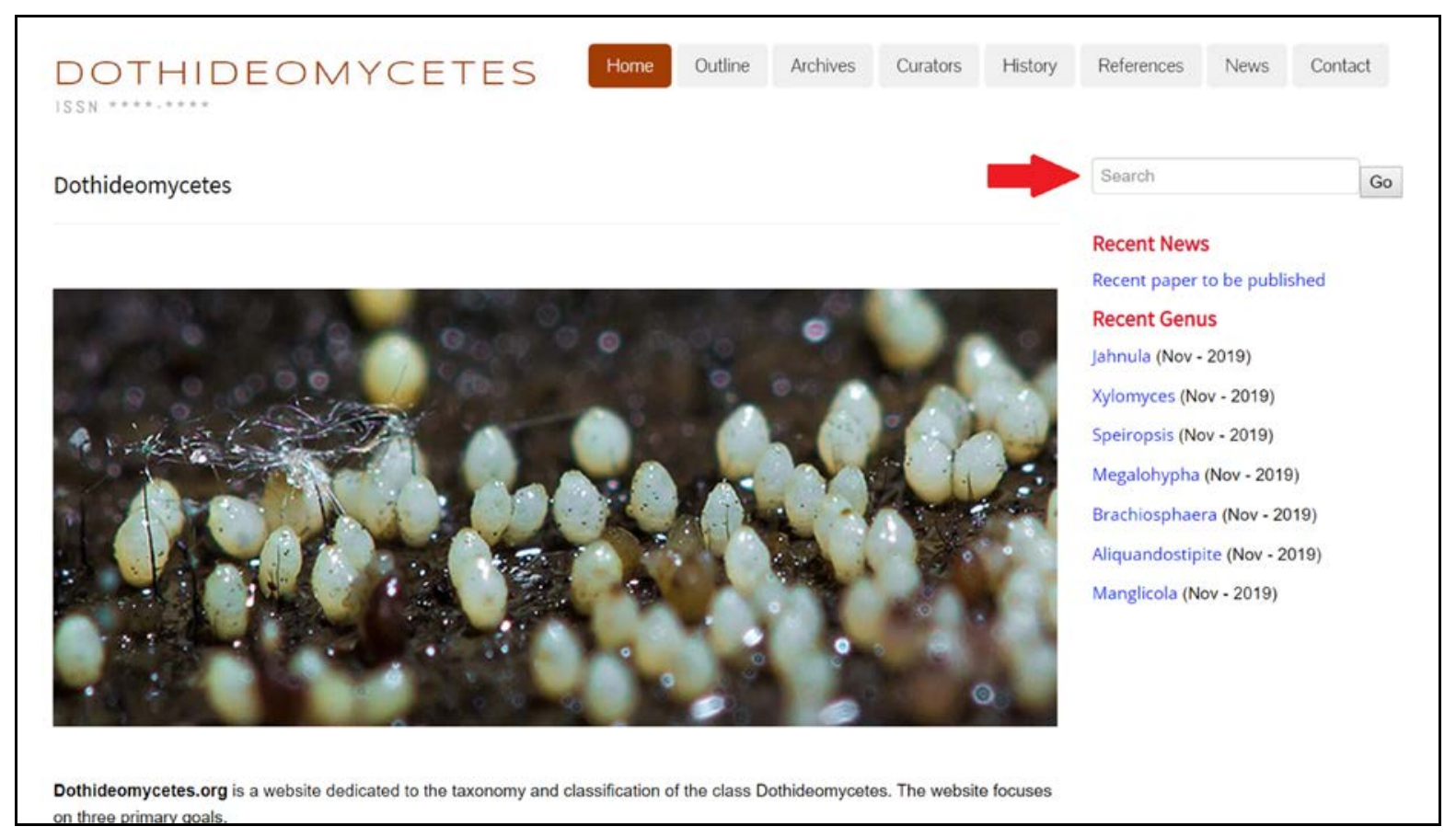

Fig. 2 - The use of search tool to find the information of genera

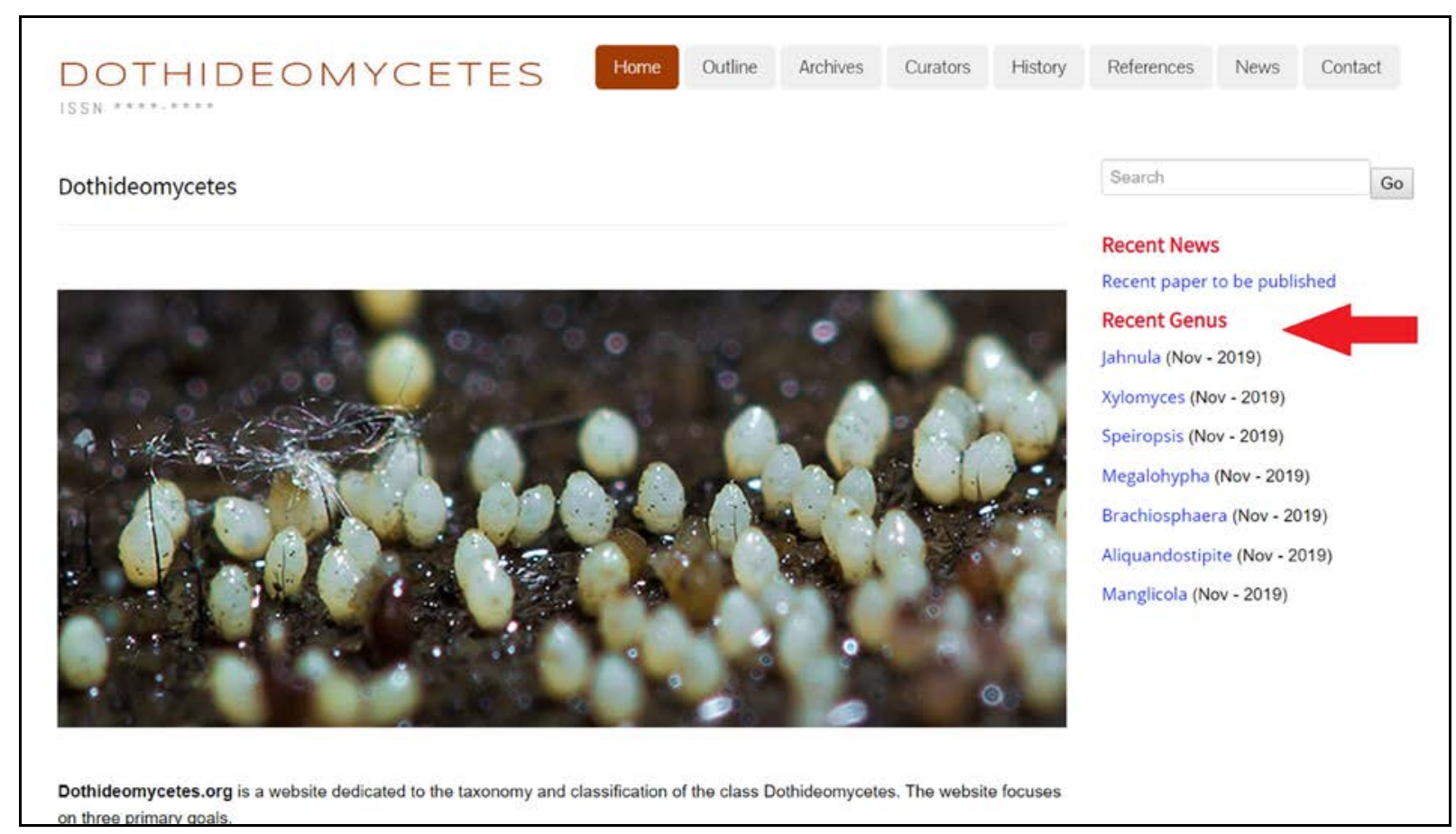

Fig. 3 - The recent genera uploaded 


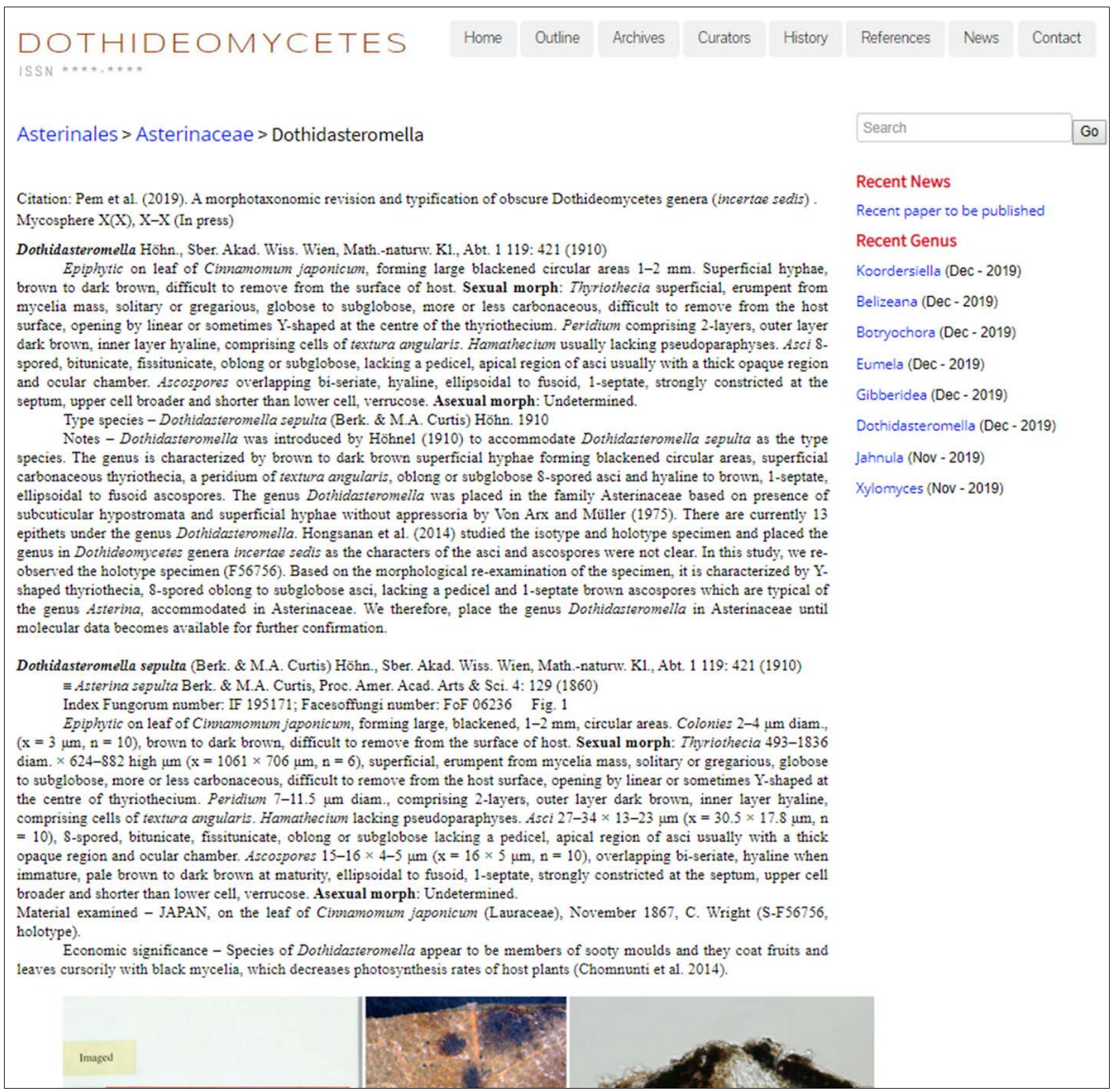

Fig. 4 - Dothideomycetes genus entry with notes and illustrations 


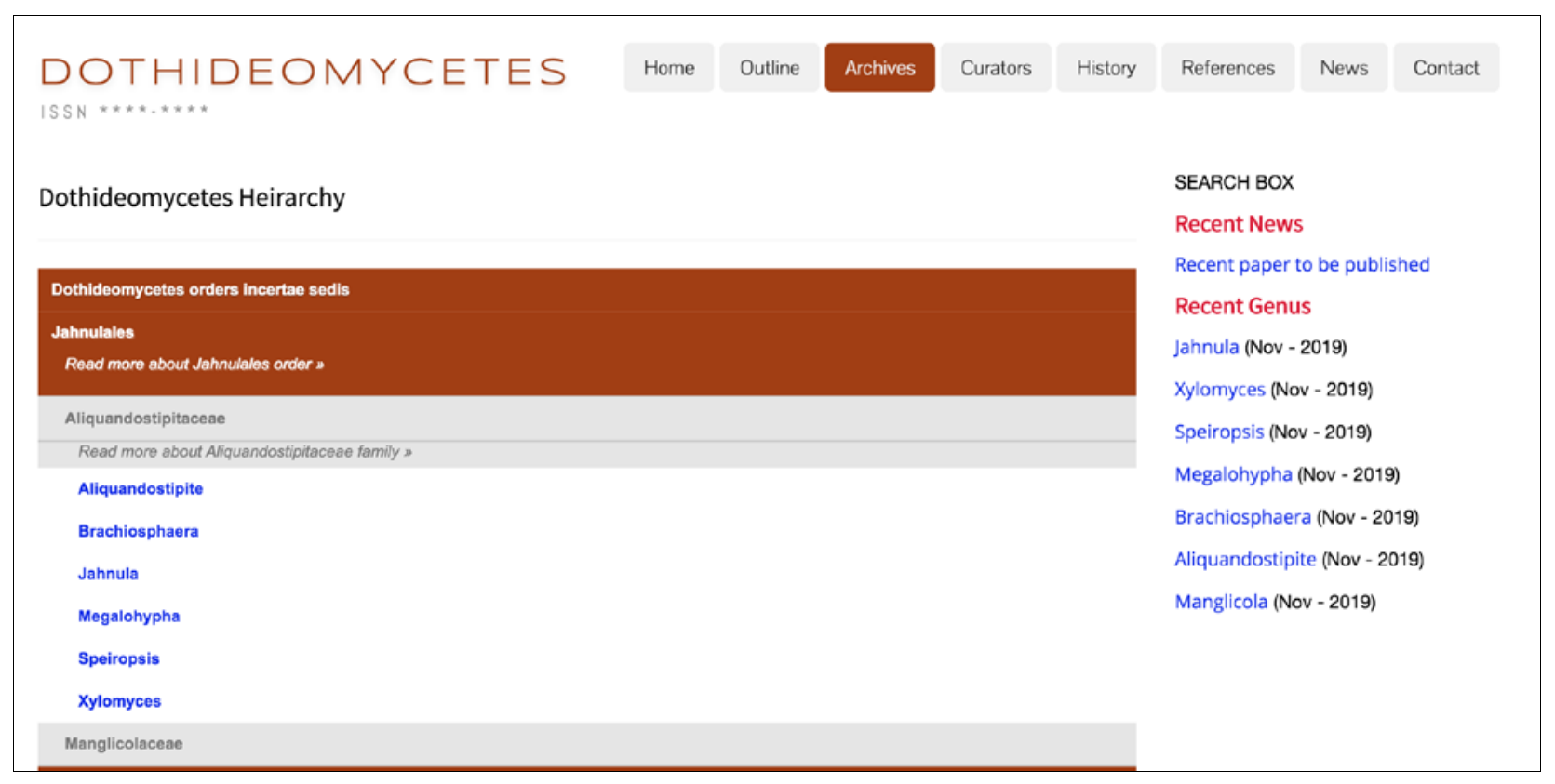

Fig. 5 - Use of Archives tool

\section{Acknowledgements}

Dhandevi Pem thanks the Mushroom Research Foundation (MRF), Thailand for financial support. Alan JL Phillips acknowledges the support from UID/MULTI/04046/2019 Research Unit grant from FCT, Portugal to BioISI. Rungtiwa Phookamsak thanks CAS President's International Fellowship Initiative (PIFI) for young staff (grant no. Y9215811Q1), the Yunnan Provincial Department of Human Resources and Social Security (grant no. Y836181261), and National Science Foundation of China (NSFC) project code 31850410489 (grant no. Y81I982211) for financial support.

\section{References}

Ariyawansa H, Kang JC, Alias S, Chukeatirote E, Hyde K. 2013 - Towards a natural classification of Dothideomycetes: The genera Dermatodothella, Dothideopsella, Grandigallia, Hysteropeltella and Gloeodiscus (Dothideomycetes incertae sedis). Phytotaxa, 147, 35-47.

Ariyawansa HA, Phukhamsakda C, Thambugala KM, Bulgakov TS et al. 2015 - Revision and phylogeny of Leptosphaeriaceae. Fungal Diversity 74, 19-51.

Ariyawansa HA, Tanaka K, Thambugala KM, Phookamsak R et al. 2014b - A molecular phylogenetic Reappraisal of the Didymosphaeriaceae (= Montagnulaceae). Fungal Diversity 68(1), 69-104.

Ariyawansa HA, Thambugala K, Kang JC, Alias S et al. 2014a - Towards a natural classification of Dothideomycetes 2: The genera Cucurbidothis, Heterosphaeriopsis, Hyalosphaera, Navicella and Pleiostomellina (Dothideomycetes incertae sedis). Phytotaxa 176, 7-17.

Barr ME. 1983 - Muriform ascospores in class Ascomycetes. Mycotaxon 18, 149-157.

Barr ME. 1984 - Herpotrichia and its segregates. Mycotaxon 20, 1-38.

Boonmee S, Phookamsak R, Hongsanan S, Doilom M et al. 2017 - Mycosphere notes 51-101. Revision of genera in Perisporiopsidaceae and Pseudoperisporiaceae and other Ascomycota genera incertae sedis. Mycosphere 8, 1695-1801.

Boonmee S, Rossman AY, Liu JK, Li WJ et al. 2014 -Tubeufiales, ord. nov., integrating sexual and asexual generic names. Fungal Diversity 68(1), 239-98.

Boonmee S, Zhang Y, Chomnunti P, Chukeatirote E et al. 2011 - Revision of lignicolous Tubeufiaceae based on morphological reexamination and phylogenetic analysis. Fungal Diversity 51(1), 63-102. 
Chomnunti P, Hongsanan S, Aguirre-Hudson B, Tian Q et al. 2014 - The sooty moulds. Fungal Diversity 66(1), 1-36.

Chomnunti P, Schoch CL, Aguirre-Hudson B, Ko Ko TW et al. 2011- Capnodiaceae. Fungal Diversity 51(1), 103-134.

Dai DQ, Bahkali AH, Bhat DJ, Xiao YP et al. 2014 -Towards a natural classification of Dothideomycetes 3: The genera Muellerites, Trematosphaeriopsis, Vizellopsis and Yoshinagella (Dothideomycetes incertae sedis). Phytotaxa 176, 18-27.

Doilom M, Dissanayake AJ, Wanasinghe DN, Boonmee S et al. 2017 - Microfungi on Tectona grandis (teak) in Northern Thailand. Fungal Diversity 82, 107-182.

Doilom M, Hyde K, Phookamsak R, Dai D et al. 2018 - Mycosphere Notes 225-274: types and other specimens of some genera of Ascomycota. Mycosphere 9, 647-754.

Hongsanan S, Hyde KD, Phookamsak R, Boonmee S et al. 2020 - Refined families of Dothideomycetes. Fungal diversity (in press)

Hongsanan S, Li YM, Liu JK, Hofmann T et al. 2014 - Revision of genera in Asterinales. Fungal Diversity 68(1), 1-68.

Hyde KD, Chaiwan N, Norphanphoun C, Boonmee S et al. 2018 - Mycosphere notes 169-224. Mycosphere 9, 271-430.

Hyde KD, Hongsanan S, Jeewon R, Bhat DJ et al. 2016 - Fungal diversity notes 367-490: taxonomic and phylogenetic contributions to fungal taxa. Fungal Diversity 80 (1), 1-270.

Hyde KD, Jones EBG, Liu JK, Ariyawansa HA et al. 2013 - Families of Dothideomycetes. Fungal Diversity 63, 1-313.

Hyde KD, Tennakoon DS, Jeewon R, Bhat DJ et al. 2019 - Fungal diversity notes 1036-1150: taxonomic and phylogenetic contributions on genera and species of fungal taxa. Fungal Diversity 96, 1-242.

Jayasiri S, Ariyawansa HA, Jones EBG, Chuan J et al. 2016 - Towards a natural classification of Dothideomycetes: 8. The genera Cocconia, Dianesea, Endococcus and Lineostroma. Phytotaxa 255, 066-074.

Jayasiri SC, Hyde KD, Ariyawansa H, Bhat DJ et al. 2015 - The Faces of Fungi database: fungal names linked with morphology, phylogeny and human impacts. Fungal Diversity 74, 3-18.

Jayasiri SC, Hyde KD, Jones EBG, McKenzie EHC et al. 2019 - Diversity, morphology and molecular phylogeny of Dothideomycetes on decaying wild seed pods and fruits. Mycosphere 10, 1-186.

Jayawardena RS, Hyde KD, McKenzie EH, Jeewon R et al. 2019 - One stop shop III: taxonomic update with molecular phylogeny for important phytopathogenic genera: 51-75. Fungal Diversity 1-84.

Jones EBG, Pang KL, Abdel-Wahab MA, Scholz B et al. 2019 - An online resource for marine fungi. Fungal Diversity 96, 347-433.

Karunarathna A, Papizadeh M, Senanayake IC, Jeewon R et al. 2017 - Novel fungal species of Phaeosphaeriaceae with an asexual/sexual morph connection. Mycosphere 8(10), 1818-1834.

Li WJ, Bhat JD, Hyde KD, Wang Y. 2014 - Towards a natural classification of Dothideomycetes 4: The genera Bryopelta, Bryorella, Bryosphaeria, Lophiosphaerella and Maireella (Dothideomycetes incertae sedis). Phytotaxa 176, 28-41.

Liu JK, Hyde KD, Jeewon R, Phillips AJL et al. 2017 - Ranking higher taxa using divergence times: a case study in Dothideomycetes. Fungal Diversity 84, 75-99.

Liu JK, Hyde KD, Jones EBG, Ariyawansa HA et al. 2015 - Fungal diversity notes 1-110: taxonomic and phylogenetic contributions to fungal species. Fungal Diversity 72, 1-197.

Lumbsch HT, Huhndorf SM. 2010 - Myconet Volume 14. Part one. Outline of Ascomycota 2009. Part Two. Notes on Ascomycete Systematics. Nos. 4751-5113. Fieldiana Life Earth Sci 1, 164.

Luo ZL, Bhat D, Jeewon R, Boonmee S et al. 2017 - Molecular Phylogeny and Morphological Characterization of Asexual Fungi (Tubeufiaceae) from Freshwater Habitats in Yunnan, China. Cryptogamie Mycologie 38, 27-53. 
Monkai J, McKenzie EHC, Phillips AJL, Hongsanan S et al. 2019 - https://fungalgenera.org/: A web-based utility of classification and notes for all genera of fungi. Asian Journal of Mycology X(X), X-X, Doi 10.5943/ajom/X/X/X (in press)

Phillips AJL, Alves A, Abdollahzadeh J, Slippers B et al. 2013 -The Botryosphaeriaceae: genera and species known from culture. Studies in Mycology 76, 51-167.

Phookamsak R, Boonmee S, Norphanphoun C, Wanasinghe DN et al. 2016 - Schizothyriaceae. Mycosphere 7(2), 154-189.

Phookamsak R, Hyde KD, Jeewon R, Bhat DJ et al. 2019 - Fungal diversity notes 929-1035: taxonomic and phylogenetic contributions on genera and species of fungi. Fungal Diversity 95, 1-273.

Phookamsak R, Hyde KD. 2015a - Fenestellaceae. Mycosphere 6(4), 402-413.

Phookamsak R, Liu JK, McKenzie EHC, Manamgoda DS et al. 2014 - Revision of Phaeosphaeriaceae. Fungal Diversity 68, 159-238.

Phookamsak R, Norphanphoun C, Tanaka K, Dai DQ et al. 2015b - Towards a natural classification of Astrosphaeriella-like species; introducing Astrosphaeriellaceae and Pseudoastrosphaeriellaceae fam. nov and Astrosphaeriellopsis, gen. nov. Fungal Diversity 74, 143-197.

Phookamsak R, Wanasinghe DN, Hongsanan S, Phukhamsakda C et al. 2017 - Towards a natural classification of Ophiobolus and ophiobolus-like taxa; introducing three novel genera Ophiobolopsis, Paraophiobolus and Pseudoophiobolus in Phaeosphaeriaceae (Pleosporales). Fungal Diversity 87, 299-339.

Rossman A, Crous PW, Hyde KD, Hawksworth DL et al. 2015 - Recommended names for pleomorphic genera in Dothideomycetes. IMA Fungus 6, 507-523.

Schoch CL, Crous PW, Groenewald JZ, Boehm EWA et al. 2009 - A class-wide phylogenetic assessment of Dothideomycetes. Studies in Mycology 64, 1-15.

Schoch CL, Shoemaker, RA, Seifert KA, Hambleton S et al. 2006 - A multigene phylogeny of the Dothideomycetes using four nuclear loci. Mycologia 98(6), 1041-1052.

Thambugala KM, Ariyawansa HA, Li YM, Boonmee S et al. 2014a - Dothideales. Fungal Diversity 68, 105-158.

Thambugala KM, Singtripop C, Chunfang Y, Mckenzie EHC et al. 2014b - Towards a natural classification of Dothideomycetes 7: the genera Allosoma, Austropleospora, Dangeardiella, Griggsia and Karschia (Dothideomycetes genera incertae sedis). Phytotaxa 181, 34-046.

Tian Q, Hongsanan S, Dai DQ, Alias SA et al. 2016 - Towards a natural classification of Dothideomycetes: clarification of Aldona, Aldonata and Viegasella (Parmulariaceae). Mycosphere 7, 511-524.

Tibpromma S, Hyde KD, Jeewon R, Maharachchikumbura SSN et al. 2017 - Fungal diversity notes 491-602: taxonomic and phylogenetic contributions to fungal taxa. Fungal Diversity 83, 1261.

Wanasinghe DN, Hyde KD, Jeewon R, Crous PW et al. 2017a - Phylogenetic revision of Camarosporium (Pleosporineae, Dothideomycetes) and allied genera. Studies in Mycology 87, 207-256.

Wanasinghe DN, Jeewon R, Jones EBG, Tibpromma S, Hyde KD. 2017b - Saprobic Dothideomycetes in Thailand: Muritestudina gen. et sp. nov. (Testudinaceae) a new terrestrial pleosporalean ascomycete, with hyaline and muriform ascospores. Studies in Fungi 2, 219-234.

Wanasinghe DN, Phukhamsakda C, Hyde K, Jeewon R et al. 2018 - Fungal diversity notes 709839: taxonomic and phylogenetic contributions to fungal taxa with an emphasis on fungi on Rosaceae. Fungal Diversity 89, 1-236.

Wijayawardene NN, Crous PW, Kirk PM, Hawksworth DL et al. 2014 - Naming and outline of Dothideomycetes-2014 including proposals for the protection or suppression of generic 9174 names. Fungal Diversity 69, 1-55. 
Wijayawardene NN, Hyde KD, Lumbsch HT, Liu JK et al. 2018 - Outline of Ascomycota: 2017. Fungal Diversity 88, 167-263.

Wijayawardene NN, Hyde KD, Rajeshkumar KC, Hawksworth DL et al. 2017 - Notes for genera: Ascomycota. Fungal Diversity 86, 1-594.

Zhang SN, Hyde KD, Jones EBG, Jeewon R et al. 2019 - Striatiguttulaceae, a new pleosporalean family to accommodate Longicorpus and Striatiguttula gen. nov. from palms. MycoKeys 49, 99-129.

Zhang Y, Crous PW, Schoch CL, Hyde KD et al. 2012 - Pleosporales. Fungal Diversity 53, 1-221. 